\title{
Policy Termination Of Alleged Crime Investigation In Polres Semarang
}

\author{
Jeifson Sitorus ${ }^{1}$ and Achmad Sulcan ${ }^{2}$
}

\begin{abstract}
Police as investigators are authorized to terminate the investigation on the grounds as stated in Section 109 subsection (2) Criminal Procedure Code. In practice, there are crime that have been conducted the investigation found sufficient evidence and suspects, but in fact people who feel harmed (victim) had not wanted the case was brought to trial. This study aims to determine the termination of the investigation policy implementation alleged criminal act in Police Semarang, barriers faced by investigators in the implementation of the termination of the investigation alleged criminal act and analyze the implementation of the termination of the investigation policy alleged criminal act that should be implemented Police. The method used is the juridical sociological with descriptive analytical research specifications. The data used are primary data and secondary data and methods of data collection through field studies and literature. Data analysis method used is qualitative analysis. The results showed that the implementation of the policy of the termination of criminal case investigation in Police Semarang conducted through restorative justice as set out in the SE Chief of Police No. SE / 8 / VII / 2018 so it does not conflict with the provisions of the law. The obstacles faced by investigators in the implementation of the termination of criminal case investigation in Police Semarang consists of internal resistance and external obstacles. As for the implementation of the policy termination criminal case investigation should be carried out in accordance with the provisions of the Police should be legislation that exists, procedural, professional, justice and uphold human rights. Reason for ending the termination of the investigation should be based on the existing Article 109 (2) Criminal Procedure Code and restorative justice with the procedures and provisions stipulated in SE Chief of Police No. SE / 8 / VII / 2018 and the Regulation No. 6 of 2019 concerning the Crime Investigation.

Keywords: Termination Of Investigation; Alleged Criminal Act.
\end{abstract}

\section{Introduction}

The Police have a very important role in uncovering the criminal case. To reveal the actual occurrence of the crime, the police conduct an investigation action. The probe is based on reports received from the victim. Prior to the commencement of a process of investigation, first has to do the investigation by investigators in a criminal case that occurred.

INP given the authority to conduct investigations and inquiries through legislation. His job as an investigator and the investigator is an important part of the Indonesian criminal justice system that have discretionary authority (discretionary power) is enormous. Police guard the gate of "fairness" and decided to report or complaint (offenses) which will be passed to continue to be investigated and, if deemed complete file will be forwarded to the Prosecutor (P-19 and P-21) or discontinued (P-14 ). One

\footnotetext{
1 Student of Master of Law, Sultan Agung Islamic University (UNISSULA), Semarang, email: jeifson sitorus@yahoo.co.id

${ }^{2}$ Lecturer of Master of Law, Sultan Agung Islamic University (UNISSULA), Semarang
} 
authority is very important here with regard to the issuance of a warrant discontinuation of the investigation (SP3 or P-14). ${ }^{3}$

In connection with the termination of the investigation, basically the police investigators were authorized by Act No. 8 of 1981 (Criminal Code) to terminate the investigation as stated in Section 109 subsection (2) Criminal Procedure Code which states that "In the case of investigators to stop the investigation because there is not enough evidence or the event turned out to be not a crime or the investigation terminated by operation of law, the investigator notify the public prosecutor, the suspect or his family. " From the wording of Article 109 paragraph (2) of the Criminal Procedure Code, there are three (3) that the reason the investigators to discontinue the investigation, namely: 1 . There is insufficient evidence; 2 . It is not a criminal offense; and 3. Discontinued by law. ${ }^{4}$

In practice, there are some criminal cases where after the evidence has been collected and the suspects had been there but it turned out later investigation on events alleged criminal acts of the investigation was stopped in the middle of the road. As for the concern is that people who feel aggrieved had not wanted the case brought to the court or the victim is not willing to give information to investigators. When the police tried to continue the criminal case, indicating that as if the Police is less seem to want to ask for rations. The reason for termination of the investigation clearly contrary to the provisions of Article 109 paragraph (2) Criminal Procedure Code, where $\mathrm{N}$ is the reason for the termination of the investigation there is not enough evidence, is not a crime, and terminated by operation of law.

Based on the above, the writer interested to do research with the title: "Policies Implementation of the Cessation of Criminal Police in Semarang "

Based on the description of the background described above, then the problem is formulated as follows: How does the policy implementation of the termination of the investigation of alleged criminal offenses in the Police Semarang?; Any obstacles encountered in the implementation of the termination of the investigation investigators alleged criminal act in Police Semarang; How to policy implementation of the cessation of criminal investigations that should be implemented by Police?

\section{Research Methods}

The method used in this research is empirical juridical approach, the research is based on the science of normative law (legislation), but instead examine the system of norms but rather to observe the reactions and interactions that occur when a system of norms that work in the community. ${ }^{5}$

Research is descriptive analytical specifications, which provide a clear, detailed and systematic. The data used are primary data and secondary data obtained through field studies and literature. The method of data analysis using qualitative analysis.

\footnotetext{
${ }^{3}$ Anne Safrina, W.M. Heri Susilowati, Maria Ulfah, "Penghentian Penyidikan:Tinjauan Hukum Administrasi dan Hukum Acara Pidana" Mimbar Hukum, Volume 20, Nomor 1, February 2017, p. 17.

${ }^{4}$ Johana Olivia Rumajar, "Alasan Pemberhentian Penyidiakn Suatu Tindak Pidana Korupsi", Lex Crimen, Vol. III/No. 4/Ags-Nov/2014, p. 93.

${ }^{5}$ Fajar Mukti ND and Achmad Yulianto, 2013, Dualisme Penenlitian Hukum Normatif dan Empiris, Yogyakarta: Pustaka Pelajara2013, p. 47.
} 


\section{Results And Discussion}

\subsection{Alleged Execution Policy Termination of Investigation Crime by Police Semarang}

Implementation of the termination of the investigation of alleged offenses in the jurisdiction of Police Semarang is guided by the Chief of Police Circular Letter No. SE / 8 / VII / 2018 on the Application of Restorative Justice (Restorative Justice) in Criminal Case Settlement. $^{6}$

Judging from the theory of police discretion, the implementation of the cessation of the investigation is a form of police discretion in handling criminal cases. It is stipulated in Article 18 of Act No. 2 of 2002 which states that "the public interest in carrying out duties Police officers and authority to act according to his own judgment." However, the act must weigh the benefits and risks and the actions to be truly in the public interest. Such action can only be performed in a state that really needs to pay attention to laws and regulations, as well as the Police Professional Code of Conduct. Likewise, Article 7, paragraph (1) letter j Criminal Procedure Code states that the investigator (any Police officer) as its obligations have the authority to conduct other actions by law responsible.

Implementation of the termination of the investigation of alleged criminal offenses in Police Semarang have also been consistent with the theory of restorative justice, which as one of the search for a peaceful settlement of the conflict out of court. In 2018 the National Police issue the Circular of the Chief of Police Number: SE / 8 / VII / 2018 on the Application of Restorative Justice (Restorative Justice) Settlement Criminal guidance on the termination of the investigation, but details of the circular has been replaced by the Police Regulation No. 6 of 2019 of Crime Investigation. In the investigation process of restorative justice can be done if they meet the conditions laid down in article 12 of the Police Regulation No. 6 of 2019 concerning the Crime Investigation.

The process of termination investigation alleged criminal act in Police Semarang have fulfilled the provisions of the SE Chief of Police No. SE / 8 / VII / 2018 as mentioned above, so it does not conflict with the provisions of the law. The agreement in the law made in order to create peace between the parties to the dispute, in which the ratio of the peace is a preventative to prevent the possibility of sustained hostility in the future between the parties litigant. In addition, the lack of peace in their letter of collective agreements then avoid legal settlement through the courts which avoids the costs incurred during the process litigate in court and avoid long delays in resolving the existing problems.

The process of termination investigation alleged criminal act in Police Semarang have also been in accordance with the theory of legal certainty. According to Lon Fuller must have certainty between regulation and its implementation, thus already entered the forms of behavior, action, and the factors that influence how positive law run with eight principle, a legal system that consists of the rules; regulations announced to the public; not retroactive because it would damage the integrity of the system; made in a formulation that is understandable by the public; there should be no conflicting

\footnotetext{
${ }^{6}$ lbid.
} 
regulations; should not require an act that exceeds what can be done; should not be frequently altered, and there should be compatibility between the regulations and the daily implementation. ${ }^{7}$

The process of termination investigation alleged criminal act in Police Semarang is guided by the legislation, namely the Criminal Procedure Code, Act No. 2 of 2002, and the Police Regulation No. 6 of 2019 concerning the Crime Investigation. Such regulations are intended to address the growing needs of the legal community and sense of fairness to all parties. Police as an institution is given the authority as investigators and investigators as well as coordinator and supervisor of criminal investigations, require regulation in criminal law enforcement system that is able to accommodate the values of fairness in society while providing legal certainty, especially the certainty of process. With the Police Regulation No. 6 of 2019 concerning the Crime Investigation, the termination process of investigation has fulfilled legal certainty.

Judging from the theory of justice, the termination process of investigation alleged criminal act in Police Semarang has fulfilled the principles of justice. As noted by John Rawls, that the principles of justice are positioned the same situation and equal between each individual in society. There are no distinctions of status, position or has a higher position among one another, so that one party to another can make a balanced agreement. ${ }^{8}$

Termination process Police Semarang investigations done after an agreement between the perpetrator to the victim to no longer continue the case to trial. Development of systems and methods of law enforcement in Indonesia showed a tendency to follow the development of the justice community, especially the development of the principles of restorative justice (restorative justice) by charging offenders with consciousness the mistake, apologized, and restore the damage and loss of victims to normal or at least resemble its original state, which can satisfy the justice of victims. With the implementation of restorative justice have reflected the principle of justice for the perpetrators and victims.

\subsection{Emerging Obstacles in Implementation BPJS in Blora and Solutions}

Based on interviews with chief of Semarang Criminal Police, it is known that the obstacles faced by investigators in the implementation of the cessation of the investigation of alleged criminal offenses in Police Semarang are as follows: ${ }^{9}$

\subsubsection{The internal resistance}

- Competence investigators and investigators maid Sat. Criminal Police Semarang in the application of the new regulations are still lacking; Rules regarding the handling of restorative justice in the criminal offense was still new and not all personnel Sat. Criminal Police Semarang better understand the content of the new rules so that any doubts or miss perception related to the implementation of these rules. To

\footnotetext{
${ }^{7}$ Lon Fuller, op.cit., p. 54-58.

${ }^{8}$ Pan Mohamad Faiz, op.cit., p. 139.

${ }^{9}$ Interview with AKP Rifeld Constantien Baba, Kasat Reskrim Polres Semarang dated February 4, 2020
} 
overcome these obstacles to be disseminated on the application of the Chief of Police Circular Letter No. SE / 8 / VII / 2018 on the Application of Restorative Justice in Criminal Case Settlement. With the socialization is expected to investigators and investigators helpers can understand considerations and procedures in the termination of the investigation of alleged criminal offenses.

- There are no special SOP related to the implementation of the termination of criminal case investigation in Police Semarang. Until now the Police Headquarters has not issued any specific SOPs outline specific investigations related to the implementation of the cessation of the underlying criminal case Kapolri Circular Letter No. SE / 8 / VII / 2018 on the Application of Restorative Justice in Criminal Case Settlement. This raises doubts investigator in the investigation at the police station termination procedure Semarang.

To overcome this problem the parties should immediately make the Police Semarang investigation SOP termination adapted to the Chief of Police Circular Letter No. SE / 8 / VII / 2018 on the Application of Restorative Justice in Criminal Case Resolution and the Regulation No. 6 of 2019 concerning the Crime Investigation.

\subsubsection{External barriers}

- Understanding of community law

Restorative justice approach in the termination of investigations sometimes have problems when there is a difference in perception related to the implementation of restorative principles in the implementation of the termination of criminal case investigation in Police Semarang. As an example of their sight does not terminate criminal compensation. It is counter productive to the purpose of retroactive justice approach and could have an impact on the loss or destruction of kinship and family values in a party-litigants.

To overcome these obstacles need their approach to the public good to amicably or socialization so that people understand that the principles of restorative justice is the principle of justice community settlement.

- Intervention from other parties

Implementation of the termination of the investigation of criminal matters in Police Semarang aims to bring justice and legal certainty for the parties litigant, but it will be complicated if where no third party has a different motivation will go in and give it form the provocative idea that makes handling more complicated cases.

To overcome these obstacles do approach to the conflicting parties not to be affected by third parties who are not interested. Against those who are related either offender, victim and community leaders involved be briefed on the purpose of settling the case through restorative justice which boils down to fairness.

- Relations between Law Enforcement Institutions

Sometimes the Prosecutor can not necessarily accept the termination of investigations conducted by the police. This is because sometimes the prosecution was not aware of any new regulations on the termination of force in police investigations. To overcome this coordination with the prosecution to provide proper grounds for termination of investigation under the provisions of the 
applicable law, namely the Regulation No. 6 of 2019 concerning the Crime Investigation.

\subsection{Implementation Policy Termination of Investigation Alleged Crime Police Are Supposed To Be Implemented}

Termination of investigation is a cessation of the investigation process has been conducted by investigators with not being forwarded to the next stage or to the prosecution stage (AGO). ${ }^{10}$ In practice, there are some cases where investigators discontinue an investigation for reasons that are not based on the provisions of Section 109 subsection (2) Criminal Procedure Code. This could happen in case of a traffic accident, an offense with a child offender, or a misdemeanor, in which cases can be settled out of court with a restorative justice approach.

As the legal basis of the investigator in the implementation of the cessation of the investigation is Article 12 of the Police Regulation No. 6 of 2019 has mandated that in the investigation process of restorative justice can be done, if certain conditions are met as mentioned in the foregoing discussion.

Police Regulation No. 6 of 2019 concerning the Crime Investigation not clearly indicating the termination procedure of investigation, but on Article 30 states that the termination of the investigation conducted by his case; the termination of the investigation can be done to fulfill the rule of law, fairness and legal expediency; and the termination of the investigation carried out in accordance with the laws and the provisions of Article 33 of the regulation invitation. Based on Police Regulation No. 6 of 2019 on Investigation Crime, then it is possible that already case back tikan investigation carried out an investigation when there are parties who filed the lawsuit. On the Police Regulation No. 6 of 2019, not described in detail the procedure for the termination of the investigation, so that in this case the police can be guided by the provisions of Circular Chief of Police No. SE / 8 / VII / 2018. The circular can be used as guidelines in the implementation of the cessation of the investigation which is the elaboration of the Police Regulation No. 6 of 2019.

Completion of the offense by restorative justice can be oriented to the Dutch state. Andi Hamzah of his visit to the Netherlands suggests that in fact $60 \%$ of cases in the hands of prosecutors in the Netherlands resolved through the process or settlement out of the judiciary (settlement out of court) or in other words by applying Restorative Justice. Meanwhile, in Indonesia, which adheres to the principle of legality, correctional institutions increasingly congested because many cases-criminal matters little person who transferred to the court. In fact, the imposition of imprisonment not necessarily a deterrent effect and is believed to be a negative learning for an inmate, as suggested by this adage: "too short for rehabilitation, too long for corruption" (in prison). ${ }^{11}$

Based on the description above, the author argues that the policy of termination investigation should be carried out by the police should be in accordance with the legal

10 Zulfan Kurnia Ainun Najib, “Akibat Hukum Penghentian Penyidikan Perkara Pidana dan Permasalahannya dalam Praktik", Diponegoro Law Review, Volume 1, Nomor 4 of 2012, p.4

11 Penyelesaian Perkara Pencurian Ringan dan Keadilan restoratif, (https://www.hukumonline.com, Accessed February 20, 2020). 
reasons as specified in Article 109 paragraph (2) Criminal Procedure Code, if there is no reason as stipulated in article 109 paragraph (2) Criminal Code, the completion of the offense by justice restorative. In this case the investigator should be able to determine the legal measures appropriate, namely by referring to the provisions of Act No. 2 of 2002 on the Police which regulates the discretion of Police, the Regulation No. 6 of 2019 on Investigation Crime and as the procedures for issuing SP3 based on the Circular of the Chief of Police No. , SE / 8 / VII / 2018 on the Application of Restorative Justice in Criminal Case Settlement, whereas in criminal acts with child actors.

Termination of investigation into alleged criminal acts with the implementation of restorative justice is absolutely necessary. This is because the development of the systems and methods of law enforcement in Indonesia showed a tendency to follow the development of the justice community, especially the development of the principles of restorative justice (restorative justice) by charging offenders with consciousness the mistake, apologized, and restore the damage and loss of victims to normal or at least resemble its original state, which could satisfy the justice of victims.

\section{Closing}

\subsection{Conclusion}

- Policy the implementation of the cessation of the criminal case investigation in Police Semarang conducted through restorative justice as stipulated in the Police Regulation No. 6 of 2019 on Investigation Crime and SE Chief of Police No. SE / 8 / VII / 2018 so it does not conflict with the provisions of the law.

- The obstacles faced by investigators in the implementation of the termination of criminal case investigation in Police Semarang consists of internal resistance and external obstacles.

- Implementation of policy termination criminal case investigation should be carried out in accordance with the provisions of the Police should be legislation that exists, procedural, professional, fair and uphold human rights.

\subsection{Suggestion}

- Need for SOPs regarding the termination of the investigation based on restorative justice as set out in the SE Chief of Police No. SE / 8 / VII / 2018.

- Need for training and special education for the members who served on the IFMS, related to receipt of the report in order to sort out the public report is already known from the beginning is not a criminal offense is not accepted as The reports of police.

- For people who feel aggrieved with SP3 which is based in SE Chief of Police No. SE / 8 / VII / 2018 may file a lawsuit against the Circular Letter.

- There should be expansion of the meaning of termination investigation citing "law", which was originally limited to the suspect died, in the crime expired needs to be expanded with when victims already have fulfilled the legal interests of criminal investigations can stopped by law. 


\section{References}

\section{Book}

[1] Fajar Mukti ND and Achmad Yulianto, 2012, Dualisme Penelitian Hukum Normatif dan Empiris, Yogyakarta: Pustaka Pelajar

\section{Laws and regulations}

[1] The Code of Criminal Procedure

[2] Act No. 2 of 2002 on the Indonesian police.

[3] Chief of Police Circular Number: SE / 8 / VII / 2018 on the Application of Restorative Justice (Restorative Justice) in Criminal Case Settlement,

\section{Journals}

[1] Anne Safrina, W.M. Heri Susilowati, Maria Ulfah, "Penghentian Penyidikan:Tinjauan Hukum Administrasi dan Hukum Acara Pidana" Mimbar Hukum, Volume 20, Nomor 1, February 2017.

[2] Johana Olivia Rumajar, "Alasan Pemberhentian Penyidiakn Suatu Tindak Pidana Korupsi", Lex Crimen, Vol. III/No. 4/Ags-Nov/2014.

[3] Zulfan Kurnia Ainun Najib, "Akibat Hukum Penghentian Penyidikan Perkara Pidana dan Permasalahannya dalam Praktik", Diponegoro Law Review, Volume 1, Nomor 4 of 2012.

\section{Website}

[1] Penyelesaian Perkara Pencurian Ringan dan Keadilan restoratif, (https://www.hukumonline.com, Accessed February 20, 2020). 